ISSN 2079-3871

\title{
A Final Guiding Hand: A Practice-Based Study into the Evolving Role of Third Party Mixers
}

\author{
Brendan Anthony \\ Griffith University \\ b.anthony@griffith.edu.edu
}

\begin{abstract}
As a mixing professional, I have noticed that the role of the third-party mixer is evolving. There is often the opportunity for the mixer to have a strong influence on the song's production. The recent delocalization of the recording studio has made professional production increasingly available to all popular musicians, and the mixer's tacit knowledge of production is valuable to artist-produced material. This project explores within a practice-based study the influence on production a mixing professional can have on a recording by an artist. The song was produced by the artist and then mixed by myself; the mixes presented here should be considered as the research in action and are intended as an aural representation of my impact on the song's production. The artist participated in an interview to help illuminate many perceptions of the adapted mixing process and its related artistic outcomes.
\end{abstract}

KEYWORDS: popular music record production, mixing.

The compositions that are part of this study can be found here:

Crimson Criminal Sydney Mix:

http://www.iaspmjournal.net/index.php/IASPM Journal/article/downloadSuppFile/817/236

Crimson Criminal:

http://www.iaspmjournal.net/index.php/IASPM_Journal/article/downloadSuppFile/817/237

\section{Introduction}

Mixing is loosely defined as "a process in which multitrack material (...) is balanced, treated and combined" (Izhaki 2008: 5). More personalized approaches suggest mixing is "refining, not reinventing" (Joe Chiccarelli cited in Massey 2000: 122) or involves a deeper connection to the song (Full Sail 2012). In the past, with

IASPM@Journal vol.7 no.2 (2017)

Journal of the International Association for the Study of Popular Music

ISSN 2079-3871 I DOI 10.5429/2079-3871(2017)v7i2.7en I www.iaspmjournal.net 
little to no involvement in the production process, third party mixers have been brought in to finalise the mix of a song. This often delivers a fresh perspective or signature sound, but regardless of approach, it is clearly the mixer's responsibility to bring together a fusion of intended musical, sonic and emotive characteristics that inspire the listener (Moylan 2002). However, Lauzon (2016) suggests that every decision made during the production process has an affect on mixing, and therefore mixing decisions are made from the pre-production process well into the recording and production proper. This study embraces these concepts and will use them to scaffold a practice-based investigation where the lines of artist, producer and mixer have been blurred.

\section{Locating the Project}

The development of the Internet and subsequent network capabilities of the recording process has changed the role of the recording studio, expanding the scope of musicians who engage with the studio, and altering the ways in which recordings are made (Thüberge 1997, 2004, 2012). Digital cultures have broadened the professional ranks of musicians, from a small number of high profile artists, to a larger pool that includes self-produced popular musicians (Burgess 2014; Draper 2016). In this context, rather than hiring a producer, artists can take on the role of producer and assume control of their musical creation (Pras Gustavino, \& Lavoie 2013).

These self-produced artists may be talented visionaries, but often lack the experience and skills of professional producers. Lefford (2015) lists these skills as music theory, performance practices, sound engineering and skills associated with communication and co-ordination. This study investigates the approaches that can be taken by mix engineers when asked to work on self-produced music where the mixer can nurture the artist's creative intentions by providing a final guiding hand for the song's production. This allows professional mixers to become entrepreneurial musical mentors, which may also increase producer/mixer earning capabilities (Burgess 2008). This article is therefore situated around the question of how the role of the mixer is evolving, focused on associate production for self-produced artists.

\section{The Study}

This study is located in Australia and within the mixing process of one selfproduced song by the artist Aquila Young (Aquila). The song was mixed by myself (the mixer), and the production has been influenced by the mixer in various stages of the recording. This practice-based approach will identify the influence that the mixer has had on the production of the song and unpack how that process took place. It is my intention that comparing the music from the initial Sydney session where the mixer had little influence on the production (the Sydney mix), to the final mix, will illustrate the role played by the mixer. This approach solidifies the musical examples as primary sources of research that represent the process in action.

Aquila was approached as a suitable participant for this study as she is a selfproduced artist of professional standard, with national airplay in Australia on the Triple J radio network (see http://www.aquilayoung.com). The recording timeline 
and elements that represent the mixer's production influence are shown in Table 1 below.

TABLE 1: Recording timeline and mixer's production influence.

\begin{tabular}{|c|c|}
\hline Recording timeline & Mixer's role, production influence \\
\hline Initial meeting & $\begin{array}{l}\text { Discuss: song selection, reference } \\
\text { material and suitable co- } \\
\text { producer/engineers. }\end{array}$ \\
\hline \multicolumn{2}{|l|}{ Sydney recording session } \\
\hline $\begin{array}{l}\text { Mid production meeting: the mixer and } \\
\text { Aquila listened to the Sydney mix }\end{array}$ & $\begin{array}{l}\text { Mixer provided production advice. } \\
\text { Song required electric guitar } \\
\text { production, lead vocal re-recording, } \\
\text { more backing vocals. }\end{array}$ \\
\hline Recording session two and three & $\begin{array}{l}\text { Following these sessions, the mixer } \\
\text { compiled a mixing session from three } \\
\text { different sessions. This included the } \\
\text { selection of parts. }\end{array}$ \\
\hline Mixing session & $\begin{array}{l}\text { The mixer added synth parts to the } \\
\text { bridge and rhythm programming to } \\
\text { chorus } 1 \text {, verse } 2 \text {, bridge and the outro } \\
\text { choruses. Complete final mix. }\end{array}$ \\
\hline 30-minute open ended discussion & \\
\hline
\end{tabular}

\section{Qualitative discussion}

Aquila and I also had a 30-minute open ended discussion after the completion of the final mix, during which I targeted a series of topics that investigated the mixer's production influence (see Appendix/Questions). Following transcription, I looked for phenomenological perspectives (Marton 1986) that could be coded as themes to represent what the mixer added as an associate producer. The following discussion is set out to align with the recording timeline. Firstly, the initial meeting and the Sydney recording session are discussed before the reader is asked to listen to the Sydney mix. This mix has no production influence by the mixer. The mixer's production influence is then identified in discussions concerning the mid production meeting, recording sessions two and three and the mixing session. The reader will then be asked to listen to the final mix, compare it to the Sydney mix and the mixer's influence on production will be heard. By listening to the music, and reading the commentary, my intention is to place the listener within a sensory experience that hears the effectiveness of the process whilst reading about what happened.

\section{Analysis and Commentary Initial meeting}

Aquila and I met for an initial meeting prior to the recording of her song "Crimson Criminal". She told me:

That first meeting was probably more just confirmation for me, knowing that I needed to (...) just stop thinking about all the possibilities (...) and just do something and make it happen (...) Who should I go to work with? What 
process should I go through? You suggested I should ask (...) what would you do? How would you go about it?

During this meeting, I heard a simplistic demo of the song. I knew Aquila needed to feel comfortable about where she recorded but It was interesting looking back now that she was hesitant to record "Crimson Criminal". She later said that "I was hesitant at the start because the demo was really bare. Listening to the last mix (...) I've been really happy with how it's come out."

In the initial meeting, I noticed Aquila was finding it hard to decide how to record the single and who to record it with. King (2016) discusses the influence technology has on creative practice and within this decision-making, suggesting that the many options available can influence creative practice decisions. Selfproduced artists need to have faith in their ability to make the right decisions, during this initial meeting I encouraged Aquila to do this so she could begin the recording process.

\section{Sydney recording sessions}

After the initial meeting Aquila decided to work with a well-established engineer with 25 years' experience at a large commercial studio in Sydney. I was interested to see if the recording session would deliver the tracks ready to be mixed. I asked Aquila how the Sydney recording sessions went, she told me that "I felt pretty horrible, I felt sick on the second day of recording (...) it was sounding (...) messy and directionless."

The term "directionless" deserves attention here. Howlett (2007) suggests that record production is a realization of a creative concept and this vision helps to design the direction of the production process. Aquila was working as coproducer with an experienced engineer yet she felt a lack of direction. The mid production meeting after the Sydney sessions helped her to unpack why this was the case.

\section{Mid production meeting}

After listening to the Sydney mix I gave Aquila some feedback on the song's production. She noticed in particular that I said "it sounded like a bed track." The song sounded bland, I suggested that it needed more musical hooks, further guitar production and, most importantly, the vocal performance and backing vocal production were unconvincing. I discussed with Aquila the importance of the producer's vision and how this should inform the musicality, sonic representation and emotional transference of a song's production (Howlett 2007, 2009). Please listen to the Sydney mix now, the mixer had little impact on the song's production in this mix.

The song was not ready to be mixed so in the mid production meeting I discussed with Aquila the role of a producer. I suggested to her that the producer needs to be the one who co-ordinates the sharing of resources by engaging with various people and their skills (Lefford 2015). I suggested that the producer was a nexus between the artist, the technology and the commercial interests invested in the project (Howlett 2009). Faced with this situation I decided my role was to empower Aquila to engage with the producer's tacit skillset that governs sonics, musicality, emotional transference and people management (Horning 2004; Howlett 2009). I sent Aquila on her way armed with specific advice regarding production and instrumentation. I also suggested she work with someone else in a 
new environment. Aquila chose to work with an engineer with 10 years' experience in a smaller studio on the Gold Coast. When she returned, the sessions needed organization but they had many of the musical elements necessary for release.

\section{The mixing session}

I then compiled the mix session from three different recording sessions. During this process I was making production decisions, selecting musical parts and compiling a session that the artist and I felt was appropriate. I also manipulated many of these traditional parts into sonic textures, for example in the introduction section. During the mixing session I added a synthesiser part and some rhythmical programming, so I felt it important to ask Aquila what she thought about a mixer adding musical elements to her production:

Aquila: "I think it depends on how the mixer goes about it and it depends on what has been added (...) but the Juno that you put in, that was really defining."

To the traditional mixer, perhaps adding instrumental parts blurs mixer/producer boundaries and manifests creative royalty queries. However, what I am suggesting is that this blurring is an extension of the mixer's evolved entrepreneurial role where such payments or credits can be negotiated at the appropriate time. This situation is similar to Kealy's (1979) provocation that the sound mixer became someone responsible for delivering an artistic interpretation rather than a sonic representation. I have developed a professional trust over a five-year period with Aquila, so I thought it would be interesting to ask her how she would feel if a mixer she hadn't worked with before added parts to her songs. She replied:

I don't know, that's a very good question! I think it depends on the style of the mixer. I imagine that you as a mixer would probably still add things if you're working with an artist for the first time and you would just communicate that really (...) clearly, and say it's there but if you don't like it, I can scrap it.

It became apparent that Aquila valued appropriate communication practices and that this supported the presentation of my production ideas to her. Please listen to the final mix now and listen for the mixer's production influence. This is exemplified by the additional production on guitar, backing vocals, synthesizer and rhythmical programming. There is also a more emotionally-connected vocal performance that engages the listener with the lyrical content and these elements (along with a professional mix) enhance the listener's aural experience compared to the Sydney mix.

\section{Conclusion}

By presenting Aquila's music it is my intention that the musical examples represent a practice-based investigation. I suggest that listening to the two mixes, a mix prior to the mixer's production input and a final mix that demonstrates the affect the mixer had on the production, illustrates that the role of the third-party mixer has evolved into that of a musical mentor. This study shows how mixing 
decisions are made throughout the production process and that mixers can engage as associate producers for self-produced artists. The thematic analysis of this research has recognized some themes that represent the mixer's engagement with production during this process. These include decision making, the producer's vision, the producer's tacit knowledge of music production, communication practices and the addition of musical parts. The role of the mixer has had a significant influence on the music's artistic representation; whether similar to this recording, a mentorship from the beginning, or simply adding what is needed during the mixing session, the mixer can provide a framework that nurtures an evolving popular musician, their creativity and their production skills. This project has explored a model of music production that relies on the role of mixer to create a high quality final product, as well as illustrating the value of practice based research in which audio exemplifies the research content present.

\section{References}

Burgess, R. J. -

2008. Producer Compensation: Challenges and Options in the New Music Business. Journal on the Art of Record Production (3). Retrieved from http://arpjournal.com/producer-compensation-challenges-and-options-in-the-newmusic-business/

2014. The History of Music Production. New York, NY: Oxford University Press.

Draper, P. 2016. Thinking through Sound: Musicianship, Record Production, and Critical Listening. In S. Frith \& S. Zagorski-Thomas, Eds. The Art of Record Production (Vol. 2). London: Ashgate.

Full Sail University. 2012. GRAMMY-Winning Mixer/Audio Engineer Chris Lord-Alge at Full Sail University. [Online] Available at http://www.youtube.com/watch?v=BGUcBhbyoF4

Horning, S. S. 2004. Engineering the Performance: Recording Engineers, Tacit Knowledge and the Art of Controlling Sound. Social Studies of Science 34 (5): 703-731. doi:10.1177/0306312704047536

Howlett, M. -

2007. Fixing the Volatile Studio: Studio Vocal Performance Techniques. Third Art of Record Production Conference, Queensland University of Technology, Brisbane. http://eprints.qut.edu.au/33275/

2009. The Record Producer as Nexus: Creative Inspiration, Technology and the Recording Industry. PhD. University Of Glamorgan.

Izhaki, R. 2008. Mixing Audio: Concepts, Practices and Tools. Oxford: Focal Press.

Kealy, E. 1979. From Craft to Art: "The Case of Sound Mixers and Popular Music".

Sociology of Work and Occupations 6 (1): 3-29.

King, A. 2016. Studio Pedagogy: Perspectives from Record Producers. In A. King \& E. Himonides Eds. Music, Technology, and Education: Critical Perspectives. New York, NY: Routledge: 45-66.

Lauzon, D. 2016. Pre-Production in Mixing: Mixing in Pre-Production. In R. HepworthSaywer \& J. Hodgson Eds. Mixing Music. New York, NY: Routledge: 114.

Lefford, M. N. 2015. The Sound of Coordinated Efforts: Music Producers, Boundary Objects and Trading Zones. Journal on the Art of Record Production (10).

Marton, F. 1986. Phenomenography: A Research Approach Investigating Different Understandings of Reality. Journal of Thought 21 (2): 28-49.

Massey, H. 2000. Behind the Glass: Top Record Producers tell how they Craft the Hits. Berkeley, CA: Miller Freeman Books.

Moylan, W. 2002. The Art of Recording: Understanding and Crafting the Mix. Boston, MA: Focal press. 
Pras, A., Guastavino, C., \& Lavoie, M. 2013. The Impact of Technological Advances on Recording Studio Practices. Journal of the American Society for Information Science and Technology 64 (3): 612-626.

Théberge, P. -

1997. Any Sound You Can Imagine: Making Music/Consuming Technology. Hanover, $\mathrm{NH}$ : University Press of New England for Wesleyan University Press.

2004. The Network Studio: Historical and Technological Paths to a New Ideal in Music Making. Social Studies of Science 34 (5): 759-781.

2012. The End of the World as We Know it: The Changing Role of the Studio in the Age of the Internet. In S. Frith \& S. Zagorski-Thomas Eds. The Art of Record Production: An Introductory Reader for a New Academic Field. Burlington, VT: Ashgate: 77-90.

\section{Appendix}

\section{Questions targeted in interview}

1. How did the discussions we had prior to mixing help influence your approach to the production of your material? How strong was your production vision prior to mixing?

2. How did the mid production meeting (after Sydney session) influence the production of the song?

3. What understanding did you have regarding what a mixer did? Has that changed?

4. Did you think the additional parts the mixer added were significant?

5. Was your vision of the song enhanced by the mixer in any artistic or musical way? How? Would you consider any of this this production?

6. Would you hire a mixer who didn't provide this service? Why? 